\title{
Genetic diversity in Capsicum baccatum is significantly influenced by its ecogeographical distribution
}

\author{
Elena Albrecht ${ }^{1}$, Dapeng Zhang ${ }^{2}$, Anne Deslattes Mays ${ }^{1}$, Robert A Saftner ${ }^{3}$ and John R Stommel ${ }^{4^{*}}$
}

\begin{abstract}
Background: The exotic pepper species Capsicum baccatum, also known as the aji or Peruvian hot pepper, is comprised of wild and domesticated botanical forms. The species is a valuable source of new genes useful for improving fruit quality and disease resistance in C. annuum sweet bell and hot chile pepper. However, relatively little research has been conducted to characterize the species, thus limiting its utilization. The structure of genetic diversity in a plant germplasm collection is significantly influenced by its ecogeographical distribution. Together with DNA fingerprints derived from AFLP markers, we evaluated variation in fruit and plant morphology of plants collected across the species native range in South America and evaluated these characters in combination with the unique geography, climate and ecology at different sites where plants originated.
\end{abstract}

Results: The present study mapped the ecogeographic distribution, analyzed the spatial genetic structure, and assessed the relationship between the spatial genetic pattern and the variation of morphological traits in a diverse C. baccatum germplasm collection spanning the species distribution. A combined diversity analysis was carried out on the USDA-ARS C. baccatum germplasm collection using data from GIS, morphological traits and AFLP markers. The results demonstrate that the C. baccatum collection covers wide geographic areas and is adapted to divergent ecological conditions in South America ranging from cool Andean highland to Amazonia rainforest. A high level of morphological diversity was evident in the collection, with fruit weight the leading variable. The fruit weight distribution pattern was compatible to AFLP-based clustering analysis for the collection. A significant spatial structure was observed in the C. baccatum gene pool. Division of the domesticated germplasm into two major regional groups (Western and Eastern) was further supported by the pattern of spatial population structure.

Conclusions: The results reported improve our understanding of the combined effects of geography, ecology and human intervention on organization of the C. baccatum genepool. The results will facilitate utilization of C. baccatum for crop improvement and species conservation by providing a framework for efficient germplasm collection management and guidance for future plant acquisitions.

\section{Background}

Capsicum baccatum, also known as the ají or Peruvian hot pepper, is a unique Capsicum species with origin in South America [1]. The species is divided into two major groups, the wild C. baccatum L. var. baccatum (formerly C. microcarpum Cav.) and the domesticated C. baccatum var. pendulum (Willd.) Eshbaugh. Morphological overlap

\footnotetext{
* Correspondence: john.stommel@ars.usda.gov

${ }^{4}$ United States Department of Agriculture, Agriculture Research Service, Beltsville Agricultural Research Center, Plant Sciences Institute, Genetic Improvement of Fruits and Vegetables Laboratory, Beltsville, MD 20705, USA Full list of author information is available at the end of the article
}

occurs between the two forms of the species [2,3]. The wild form of the species typically bears small, erect, deciduous fruit, whereas the domesticated form typically bears larger sized, pendant and persistent fruit [4]. Human selection pressure promoted increased fruit size and weight with resultant downwards bending of the pedicel. Hence, the name 'pendulum' derived from the Latin pendulus for hanging fruit.

The earliest historical specimens of C. baccatum date to $2000 \mathrm{BC}$ [5]. Historical documents demonstrate the significance of the fruit in ancient American, including Incan and earlier cultures. Contrary to the other four 
recognized domesticated Capsicum species (C. annuum, C. chinense Jacq., C. frutescens $\mathrm{L}$. and C. pubescens), domesticated forms of C. baccatum are not commonly distributed outside South America. C. baccatum var. pendulum is the domesticated pepper of choice in Bolivia, Ecuador, Peru and Chile, and the most frequently grown pepper species in South America [6].

The center of origin for C. baccatum is believed to lie in Bolivia and southern Peru $[4,7,8]$. Domestication of the species is a relatively recent event in comparison to many cultivated crops and occurred approximately 4,500 years ago in Peru $[3,9,10]$ and possibly at other sites of the present wild distribution range. Recent studies evaluating genus-specific starch fossils indicate the use of domesticated peppers as early as 6,000 years ago [11]. Utilizing amplified fragment length polymorphism (AFLP) genotypes [12], we previously demonstrated that genetic diversity in the wild form of $C$. baccatum ( $C$. baccatum var. baccatum) was greater than in the domesticated form of the species (C. baccatum var. pendulum). Furthermore, we demonstrated admixture/shared ancestry between wild and domesticated C. baccatum botanical varieties and that the domesticated $C$. baccatum germplasm constitutes two principal genetic groups, largely based on their geographic distribution. One group was composed predominantly of cultigens from the western territories of the species' distribution (Peru, Colombia, Ecuador, Bolivia, Chile and western Argentina) and the second of cultigens from the eastern regions (Brazil, Paraguay and eastern Argentina). The two genetic groups overlapped in the geographic location of present day Bolivia. The grouping pattern suggested that the cultigens of $C$. baccatum were domesticated at multiple sites and that their evolution followed two major lineages followed by lineage differentation. The wild accessions most closely related to the cultigens were found in the highlands of Peru and Bolivia, which supports the early hypothesis that this region is one of the domestication sites of this species. A Bayesian assignment analysis demonstrated that Brazilian wild forms of C. baccatum were genetically distant to all other accessions and made little to no contribution to the domesticated gene pool [12].

The United States Department of Agriculture, Agriculture Research Service (USDA, ARS) C. baccatum germplasm collection is comprised of accessions collected from a wide range of ecogeographical areas in South America. Phenotypic and genetic diversity of Capsicum

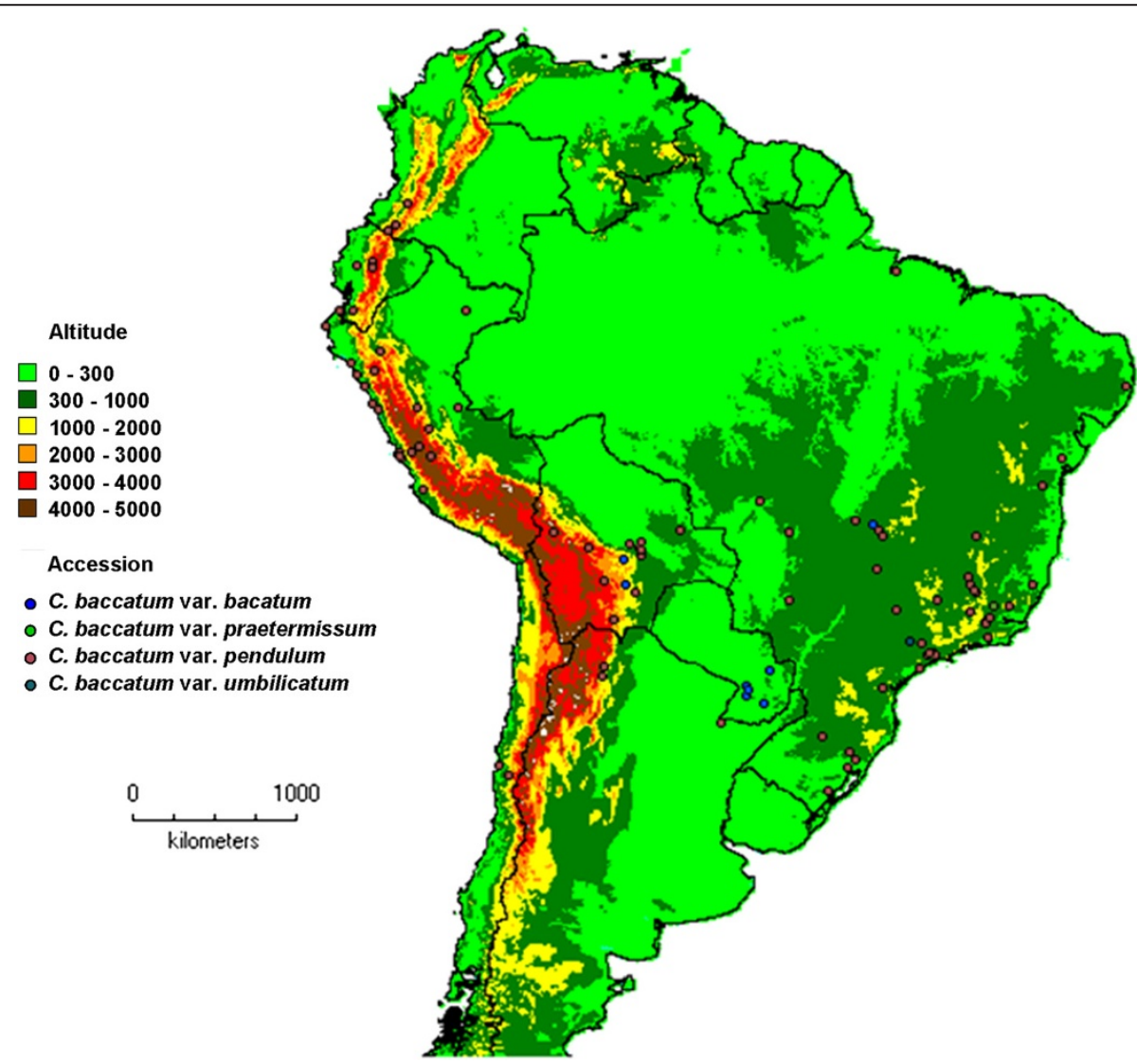

Figure 1 Geographic distribution of the USDA, ARS Capsicum baccatum germplasm collection. DIVA-GIS [14] was utilized for constructing the distribution map of the C. baccatum collection. 
in each of these areas is affected by geography, climate, ecology and human intervention. Improved understanding of the combined effects of these factors on the current structure of genetic diversity and morphological variation within the species is important for efficient germplasm conservation and use [13]. In the present study, a meta-analysis was utilized to describe diversity of the USDA, ARS C. baccatum germplasm collection using data from a geographic information system (GIS), morphological traits and AFLP-derived DNA fingerprints. Our objectives included: 1) mapping the ecogeographic distribution of the C. baccatum collection; 2) analyzing the spatial genetic structure in domesticated C. baccatum germplasm; and 3) assessing the relationship between the spatial genetic pattern and variation in morphological traits. The results will improve our knowledge of the structure of genetic diversity in C. baccatum germplasm, thus enhancing the conservation of this species and its utilization in pepper breeding.

\section{Results}

\section{Ecogeographical distribution}

Capsicum baccatum occupies a diverse geographic range in South America (Figure 1, Tables 1 and 2). The maximal distance between any two accessions of the wild form of the species, $C$. baccatum var. baccatum and $C$. baccatum var. praetermissum, evaluated in this analysis was greater than $3,200 \mathrm{~km}$ and occurred between an accession from the Peruvian Andes, PI215699, and one from the coastal region in Southern Brazil, PI260533. The maximal distance between any two accessions of the domesticated form of the species, C. baccatum var. pendulum and C. baccatum var. umbilicatum, was greater than 5,000 km and occurred between an accession on the western coast of Peru, PI257151, and one on the eastern coast of Brazil, PI1520.

The domesticated accessions (C. baccatum var. pendulum, C. baccatum var. umbilicatum) analyzed in this study covered a latitudinal distance ranging from -31 to 2.5 degrees and a longitudinal distance ranging from -81.3 to -35.3 degrees with a median of -17.8 degrees latitude/-57.2 degrees longitude in western Brazil, MatoGrosso do Sul, at the border of Bolivia (Figure 1). Accessions of the wild forms of the species (C. baccatum var. baccatum, C. baccatum var. praetermissum) covered a smaller range from -29.6 to -11.53 degrees latitude and -75.9 to -2.9 degrees longitude with a median of -20.8 degrees latitude /-57.1 degrees longitude in western Brazil, MatoGrosso do Sul, at the border of Bolivia and Paraguay.

Capsicum baccatum occupies altitudinal extremes across its geographic distribution (Figure 1, Table 2). Accessions, both wild and domesticated, grow from sea level (e.g. Pará, Brazil) to over 4,000 m (e.g. Junín, Peru).
Table 1 List of selected Capsicum baccatum accessions with GIS data from the USDA, ARS Capsicum germplasm collection

\begin{tabular}{|c|c|c|}
\hline Source & Region $^{z}$ & $\begin{array}{l}\text { Number of } \\
\text { accessions }\end{array}$ \\
\hline \multicolumn{3}{|c|}{ C. baccatum var. pendulum } \\
\hline Argentina & Corrientes, Jujuly, NA & 3 \\
\hline Bolivia & $\begin{array}{l}\text { Chuquisaca, Cochabamba, } \\
\text { El Beni, La Paz, Potosí, } \\
\text { Santa Cruz, Tarija, NA }\end{array}$ & 26 \\
\hline Brazil & $\begin{array}{l}\text { Bahia, Espírito Santo, Goiás, } \\
\text { Mato Grosso, Mato Grosso do Sul, } \\
\text { Minas Gerais, Pará, Paraná, } \\
\text { Pernambuco, Rio de Janeiro, } \\
\text { Rio Grande do Sul, São Paulo, NA }\end{array}$ & 81 \\
\hline Chile & Cochimbo, NA & 3 \\
\hline Colombia & Cauca, Nariño & 2 \\
\hline Ecuador & $\begin{array}{l}\text { Carchi, Chimborazo, Cotopaxi, } \\
\text { El Oro, Imbabura, Loja, Los Rios, } \\
\text { Tungurahura, NA }\end{array}$ & 15 \\
\hline Paraguay & $\begin{array}{l}\text { Alto Paraná, Asunción, Cordillera, } \\
\text { Guaíra, Itapúa, Paraguarí }\end{array}$ & 15 \\
\hline Peru & $\begin{array}{l}\text { Amazonas, Ancash, Cajamarca, } \\
\text { Huánuco, Ica, Junín, La Libertad, } \\
\text { Lambayeque, } \\
\text { Lima, Loreto, Pasco, Piura, } \\
\text { Tumbes, Ucayali }\end{array}$ & 52 \\
\hline \multicolumn{3}{|c|}{ C. baccatum var. umbilicatum } \\
\hline Brazil & São Paulo & 1 \\
\hline \multicolumn{3}{|c|}{ c. baccatum var. baccatum } \\
\hline Bolivia & $\begin{array}{l}\text { Chuquisaca, Cochabamba, } \\
\text { Santa Cruz, NA }\end{array}$ & 7 \\
\hline Brazil & Goiás, Rio Grande do Sul, NA & 4 \\
\hline Paraguay & Caazapá, Cordillera, Paraguarí & 5 \\
\hline Peru & Junín, NA & 4 \\
\hline \multicolumn{3}{|c|}{ C. baccatum var. praetermissum } \\
\hline Brazil & Minas Gerais & 2 \\
\hline
\end{tabular}

${ }^{\mathrm{z}} \mathrm{NA}$, geographic data not available for all accessions.

Approximately $50 \%$ of the accessions analyzed were found at altitudes below $500 \mathrm{~m}$. The lowland accessions occur in the Amazon basin and the coastal regions of Ecuador, Peru, and Chile in the west and Brazil in the east. The highland accessions (above 2,000 $\mathrm{m}$ altitude) inhabit eastern and western sides of the Andes in Ecuador, Peru and Bolivia. Wild accessions occupy higher altitudes compared to domesticated ones. Fifty percent of the wild accessions grow at altitudes ranging from $210 \mathrm{~m}$ to $2,030 \mathrm{~m}$ (median $740 \mathrm{~m}$ ). Approximately 50\% of the domesticated accessions are found at altitudes ranging from $170 \mathrm{~m}$ to $780 \mathrm{~m}$ (median $510 \mathrm{~m}$ ).

Average annual temperatures in the native $C$. baccatum habitat span $5^{\circ} \mathrm{C}$ (e.g. in Junín, Peru) to $27^{\circ} \mathrm{C}$ (e.g. Pará, Brazil and Loreto, Peru), with a median of $20^{\circ} \mathrm{C}$ for both wild and domesticated forms of the species 
Table 2 Variation range of ecogeographic factors in the USDA, ARS Capsicum baccatum germplasm collection

\begin{tabular}{lcc}
\hline Ecogeographic factors & $\begin{array}{c}\text { Lower } \\
\text { extreme }\end{array}$ & $\begin{array}{c}\text { Upper } \\
\text { extreme }\end{array}$ \\
\hline Latitudinal distance & -31 & 2.5 \\
Longitudinal distance & -81.3 & -35.3 \\
Altitude (m.a.s.l) & 1 & 4,008 \\
Average annual temperatures $\left({ }^{\circ} \mathrm{C}\right)$ & 5 & 27 \\
Maximum temperature $\left({ }^{\circ} \mathrm{C}\right)$ & 13 & 34 \\
Minimum temperature $\left({ }^{\circ} \mathrm{C}\right)$ & -5 & 22 \\
Annual rainfall $(\mathrm{mm})$ & 3 & 2,849 \\
Precipitation during the warmest quarter $(\mathrm{mm})$ & 0 & 1,226 \\
\hline
\end{tabular}

(Table 2). Nearly $50 \%$ of the accessions evaluated occupy areas with average annual temperatures that range from $19^{\circ} \mathrm{C}$ to $22^{\circ} \mathrm{C}$. The average minimum temperatures recorded for $\mathrm{C}$. baccatum habitats are $6^{\circ} \mathrm{C}$ to $11^{\circ} \mathrm{C}$ for the wild accessions (C. baccatum var. baccatum, C. baccatum var. praetermissum) and $9^{\circ} \mathrm{C}$ to $13^{\circ} \mathrm{C}$ for the domesticated accessions (C. baccatum var. pendulum, $C$. baccatum var. umbilicatum). Approximately $10 \%$ of wild and domesticated accessions are regularly exposed to chilling temperatures $\left(0-5^{\circ} \mathrm{C}\right)$, and those at high altitudes in the Andes (Junín, Peru) may experience freezing temperatures $\left(-5^{\circ} \mathrm{C}\right)$. The warmest regions of the $C$. baccatum habitat are typically the continental areas, e.g. the Amazon basin of Brazil, but also tropical coastal regions such as those in Ecuador which are exposed to warm temperatures in the summer. In most areas of the distribution, C. baccatum is exposed to a maximum temperature of $28^{\circ} \mathrm{C}$ to $31^{\circ} \mathrm{C}$ and to over $34^{\circ} \mathrm{C}$ in a few of the continental or tropical coastal regions. In contrast, temperatures hardly fall below $25^{\circ} \mathrm{C}$ at some of the tropical habitat sites in the C. baccatum distribution.

Annual rainfall conditions are diverse in the C. baccatum distribution range (Table 2). Populations in regions along the western coast of South America are exposed to little rainfall during the summer months. In regions closer to the equator, higher temperatures are accompanied by greater amounts of rainfall. The majority of accessions analyzed, both wild and domesticated, receive $500-1,500 \mathrm{~mm}$ rainfall per year $($ median $=1,250 \mathrm{~mm}$ ). Fifteen percent of the C. baccatum accessions evaluated grow in desert-like territories with less than $30 \mathrm{~mm}$ rainfall per year, e.g. Peruvian coastal areas. In contrast, on the eastern side of the Andes in the continental, tropical area of Peru (Loreto), precipitation rates are the highest for the C. baccatum distribution range, reaching almost $3,000 \mathrm{~mm}$.

Notable with respect to the amount of rainfall in occupied habitats is the difference between C. baccatum var. baccatum and C. baccatum var. pendulum. While $C$. baccatum var. baccatum accessions did not occur at sites with less than $500 \mathrm{~mm}$ rainfall per year (e.g. Cochabamba, Bolivia), domesticated accessions occupied habitat with just $3 \mathrm{~mm}$ rainfall per year (La Libertad, Peru). Some domesticated accessions occupied areas with $0 \mathrm{~mm}$ precipitation during the warmest quarter of the year. In contrast, wild accessions in the collection were restricted to areas with a minimum of $150 \mathrm{~mm}$ during the warmest quarter. For both wild and domesticated accessions, the median amount of precipitation was $390 \mathrm{~mm}$.

\section{Association between ecogeographic factors and morphological traits}

Longitude, altitude, annual rainfall, annual temperature, maximum temperature during the warmest month, and minimum temperature during the coldest month were all associated with morphological variation in the 190 accessions of C. baccatum (Table 3). Among these ecogeographic factors, annual rainfall, followed by maximum temperature in the warmest month, precipitation in the warmest quarter and minimum temperature

\section{Table 3 Association between ecogeographic factors and morphological traits in the USDA, ARS Capsicum baccatum germplasm collection}

\begin{tabular}{|c|c|c|}
\hline $\begin{array}{l}\text { Morphological traits } \\
\text { (Dependent) }\end{array}$ & Ecogeographic factors (Label) & F value \\
\hline Stem number & Precipitation warmest quarter & $8.53^{* *}$ \\
\hline Plant height & Longitude & $5.00^{*}$ \\
\hline Plant habit & $\begin{array}{l}\text { Minimum temperature } \\
\text { coldest month }\end{array}$ & $5.23^{*}$ \\
\hline Locule number & Annual rainfall & $10.37^{* *}$ \\
\hline Immature fruit color & $\begin{array}{l}\text { Minimum temperature } \\
\text { coldest month }\end{array}$ & $5.02^{*}$ \\
\hline Fruit set (low to high) & Annual rainfall & $4.54^{*}$ \\
\hline $\begin{array}{l}\text { Fruit position } \\
\text { (pendant to erect) }\end{array}$ & $\begin{array}{l}\text { Maximum temperature } \\
\text { warmest month }\end{array}$ & $4.38^{*}$ \\
\hline $\begin{array}{l}\text { Fruit persistance } \\
\text { (seperating/persitent) }\end{array}$ & Longitude & $6.23^{*}$ \\
\hline Days to maturity & $\begin{array}{l}\text { Maximum temperature } \\
\text { warmest month }\end{array}$ & $9.06^{* *}$ \\
\hline Days to maturity & Annual temperature & $8.21^{* *}$ \\
\hline Calyx shape (cup/saucer) & Precipitation warmest quarter & $7.61^{* *}$ \\
\hline Calyx shape (cup/saucer) & Altitude & $6.50^{*}$ \\
\hline $\begin{array}{l}\text { Calyx margin } \\
\text { (smooth to serrate) }\end{array}$ & Annual rainfall & $17.46^{* * *}$ \\
\hline $\begin{array}{l}\text { Calyx margin } \\
\text { (smooth to serrate) }\end{array}$ & $\begin{array}{l}\text { Minimum temperature } \\
\text { coldest month }\end{array}$ & $6.94^{* *}$ \\
\hline $\begin{array}{l}\text { Calyx margin } \\
\text { (smooth to serrate) }\end{array}$ & Annual temperature & $6.12^{*}$ \\
\hline Anthocyanin immature fruit & Altitude & $5.78^{*}$ \\
\hline
\end{tabular}

***, **, ${ }^{*}$ Significant at $0.05,0.01$ and 0.001 , respectively. 
during the coldest quarter, exhibited the strongest associations with morphological traits. However, no association was detected between latitude and morphological traits in C. baccatum germplasm.

Substantial morphological differences were detected between the western and eastern groups (Table 4). For fruit attributes, fruit weight and fruit width in the western group were reduced relative to that recorded for the eastern group. Similarly, wall thickness was also reduced in the western group. No significant difference was detected for fruit length. Fruit maturation time was greater and fruit set slightly less for western accessions in comparison to eastern accessions. Immature fruits of eastern accessions are more likely to contain anthocyanin. The calyx margins are more serrate in varieties of the western group, and fruit persistence is somewhat reduced relative to eastern accessions.

With several exceptions, morphological differences for traits affecting plant architecture did not differ between western and eastern groups. The average plant height was $13 \mathrm{~cm}$ less in the west compared to the east, whereas stem number was greater.

\section{Morphological variation in wild and domesticated $C$. baccatum}

Significant differences were observed in morphological traits between wild and domesticated $C$. baccatum accessions. Stem number, fruit length, width, weight, locule number, wall thickness, and peduncle length were all significantly reduced in C. baccatum var. baccatum versus $C$. baccatum var. pendulum (Table 5). All wild accessions exhibited abscising fruit while fruit of domesticated types were generally persistent. Corolla color of wild accessions was generally white or green-white and less frequently with violet coloration. Corollas of domesticated accessions lacked anthocyanin pigmentation. Similar to corolla pigmentation, domesticated accessions were less likely to exhibit anthocyanin pigmented immature fruit.

Based on random forest estimates, $49 \%$ of the total morphological variation in $C$. baccatum can be explained by separation of the $C$. baccatum collection into two major groups, the wild and the domesticated forms of the species (Figure 2). Fruit weight was the variable of greatest importance (increasing node purity= 16.79) that distinguished wild versus domesticated types, followed by fruit width (increasing node purity $=13.22$ ) and peduncle length (increasing node purity $=7.72$ ). The contribution of features with the highest importance that distinguished the two taxa based on random forest regression (i.e. fruit weight, fruit width and peduncle length) was tested via multivariate analysis of variance (MANOVA). All four significance tests (Wilks, Hotelling-Lawley, Roy, Pillai) rejected the null hypothesis that the mean of the composite variable was the same as that for the individual groups (C. baccatum var. baccatum and $C$. baccatum var. pendulum), hence confirming the significance of the features for separation of the taxa. The proportion of the variance that is accounted for by the (composite) predictors was $28 \%$ (1 - Wilks' lambda) $* 100=(1-0.70) * 100)$.

Cluster analysis demonstrated that $C$. baccatum fruit traits including fruit weight and fruit length are closely associated with each other and somewhat independent from the remainder of the morphological traits (Figure 3). Fruit width and peduncle length clustered together with plant height and plant width. Degree of pungency was associated with days to maturity. Anthocyanin production in vegetative plant parts, i.e. nodes and stems, was correlated.

\section{Spatial genetic structure}

Mantel test revealed significant spatial correlation among the 174 accessions of domesticated $C$. baccatum $(r=0.17, P<0.001)$. Correlation among the 92 accessions of the western group $(r=0.27, P<0.001)$ was similar to that in the overall domesticated group. No significant correlation was detected among the 90 accessions of the eastern group $(r=0.05, P=0.053)$.

Significant spatial genetic structure was detected in domesticated $C$. baccatum accessions at equally-sized distance, with distance class sizes of $50 \mathrm{~km}$ (Figure 4). The structure was maintained over geographic distances up to $1,750 \mathrm{~km}$ (= 'limits of dispersal'). However, correlations were strongest $(r=0.2$ to 0.35$)$ within a radius smaller than $100 \mathrm{~km}$.

When a varying number of clusters were assumed, spatial population genetic analysis based on the Bayesian clustering algorithm demonstrated a division of the domesticated germplasm into two major groups, a western and an eastern spatial cluster (Figure 5). A small number of individuals shared membership among groups or geographic locations. Spatial cluster results provided a clearer delineation among western and eastern groups in comparison to our previous result based only on DNA fingerprints. The boundary between the two groups corresponded to today's political borders for Peru/Bolivia and Paraguay/Brazil.

\section{Discussion}

\section{Ecogographic distribution and adaptation}

Capsicum baccatum displays a wide geographic distribution across the South American continent from the west coast to the east coast, and from Columbia in the north to Chile in the south. The variability of ecological and climatic conditions along the broad geographic range is extensive. This broad geographic range contributes to the great diversity found in $C$. baccatum and related 
Table 4 Average morphological tratis in the 'western' and 'eastern' group of Capsicum baccatum germplasm accessions

\begin{tabular}{|c|c|c|c|}
\hline Morphological traits & Western & Eastern & $P$ value $^{\mathrm{Z}}$ \\
\hline Anther color [1 = yellow, 2 =yellow/blue] & 1.08 & 1.03 & NS \\
\hline Anthocyanin immature fruit [ $1=$ present, $0=$ absent $]$ & 0.08 & 0.25 & 0.0313 \\
\hline Blossom end shape $[1=$ pointed, $9=$ sunken $]$ & 1.88 & 2.14 & NS \\
\hline Calyx constriction $[1=$ present, $0=$ absent $]$ & 0 & 0.02 & NS \\
\hline Calyx margin [1 = smooth, $9=$ serrate $]$ & 5.05 & 3.87 & 0.0001 \\
\hline Calyx shape $[1=$ cup, $2=$ saucer $]$ & 1.09 & 1.31 & NS \\
\hline Corolla color $[1=$ white, 2 = green-white, $5=$ violet $]$ & $1=100 \%$ & $1=100 \%$ & NS \\
\hline Corolla spots $[2=$ yellow, $3=$ green/yellow $]$ & $2=92 \%, 3=8 \%$ & $2=89 \%, 3=11 \%$ & NS \\
\hline Days to maturity [1 = early, $9=$ late $]$ & 6.12 & 5.28 & 0.0142 \\
\hline Degree of pungency [1 = sweet, $9=$ pungent $]$ & 5.68 & 5.71 & NS \\
\hline Determinate habit $[1=$ at least $75 \%$ mature at once, $0=$ absent $]$ & 0.04 & 0.05 & NS \\
\hline Fasiculate $[1=$ present, $0=$ absent $]$ & 0.05 & 0.12 & NS \\
\hline Fruit corkiness $[0=$ none, $9=$ very high $]$ & 0.10 & 0.01 & NS \\
\hline Fruit length $[\mathrm{cm}]$ & 6.00 & 5.80 & NS \\
\hline Fruit neck constriction $[1=$ present, $0=$ absent $]$ & 0.02 & 0.08 & NS \\
\hline $\begin{array}{l}\text { Fruit persistance }[0=\text { separating calyx (has } S p \text { gene), } \\
0=\text { persistant calyx }]\end{array}$ & 0.47 & 0.85 & $<0.001$ \\
\hline Fruit pods per node & 1.00 & 1.02 & NS \\
\hline Fruit position $[1=$ pendant, $9=$ erect $]$ & 2.87 & 1.94 & NS \\
\hline Fruit set $[1=$ low, $9=$ high $]$ & 6.25 & 6.83 & 0.0028 \\
\hline Fruit shape $[1=$ elongate, $2=$ oblate, $4=$ conic, $6=$ bell $]$ & $1=88 \%, 4=12 \%$ & $1=81 \%, 2=2 \%, 4=9 \%, 6=9 \%$ & NS \\
\hline Fruit weight $[\mathrm{g}]$ & 4.40 & 6.00 & 0.014 \\
\hline Fruit width $[\mathrm{cm}]$ & 1.70 & 2.00 & 0.0381 \\
\hline $\begin{array}{l}\text { Immature fruit color [2= green, } 3=\text { green/yellow, } \\
4=\text { yellow, } 5=\text { white }]\end{array}$ & $2=62 \%, 3=30 \%, 4=6 \%, 5=3 \%$ & $2=52 \%, 3=40 \%, 4=3 \%, 5=5 \%$ & NS \\
\hline Leaf pubescence $[0=$ glabrous, $9=$ excessive $]$ & 0.05 & 0.02 & NS \\
\hline Leaf texture $[1=$ smooth, $9=$ curled $]$ & 1.08 & 1.06 & NS \\
\hline Locule number & 2.94 & 2.61 & 0.0063 \\
\hline $\begin{array}{l}\text { Mature fruit color: Griffin }+ \text { USDA observations } \\
{[2=\text { red, } 3=\text { orange-red, } 4=\text { yellow, } 5=\text { orange }]}\end{array}$ & $2=73 \%, 3=9 \%, 4=17 \%$ & $2=89 \%, 3=3 \%, 4=1 \%, 5=7 \%$ & 0.0536 \\
\hline Node anthocyanin $[1=$ present, $0=$ absent $]$ & 0.89 & 0.92 & 0.0078 \\
\hline Pedicel position at anthesis $[1=$ pendant, $9=$ erect $]$ & 8.36 & 8.79 & $<0.001$ \\
\hline Peduncle insertion $[1=$ protruded, $9=$ inserted $]$ & 2.69 & 3.12 & NS \\
\hline Peduncle length $[\mathrm{cm}]$ & 4.40 & 3.90 & NS \\
\hline Plant habit [1 = sprawling, $9=$ tall or upright $]$ & 5.54 & 5.18 & NS \\
\hline Plant height $[\mathrm{cm}]$ & 61.70 & 74.70 & $<0.0011$ \\
\hline Plant width $[\mathrm{cm}]$ & 78.76 & 86.38 & NS \\
\hline Stem anthocyanin $[1=$ present, $0=$ absent $]$ & 0.79 & 0.77 & $<0.001$ \\
\hline Stem color [1 = green, 2 = purple] & 1.00 & 1.00 & NS \\
\hline Stem number & 6.52 & 5.73 & 0.0402 \\
\hline Stem pubescence $[0=$ glabrous, $9=$ excessive $]$ & 0.85 & 0.69 & NS \\
\hline Stigma exsertion $[1=$ inserted, $9=$ exserted $]$ & 4.44 & 4.13 & NA \\
\hline Wall thickness [cm] & 0.14 & 0.19 & 0.0028 \\
\hline
\end{tabular}

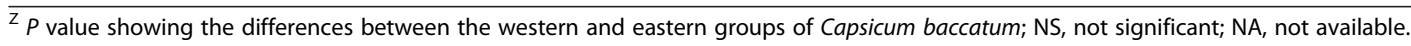


Table 5 Average morphological traits in 190 accessions of wild and domesticated Capsicum baccatum germplasm accessions

\begin{tabular}{|c|c|c|c|}
\hline Morphological traits & Wild & Domesticated & $P$ value \\
\hline Anther color [1 =yellow, $2=$ yellow/blue $]$ & 0 & 0.06 & NS \\
\hline Anthocyanin immature fruit $[1=$ present, $0=$ absent $]$ & 0.56 & 0.16 & 0.031 \\
\hline Blossom end shape $[1=$ pointed, $9=$ sunken $]$ & 2.40 & 2.00 & NS \\
\hline Calyx constriction [ $1=$ present, $0=$ absent $]$ & 0 & 0.01 & NS \\
\hline Calyx margin $[1=$ smooth, $9=$ serrate $]$ & 5.00 & 4.50 & NS \\
\hline Calyx shape $[1=$ cup, 2 = saucer $]$ & 1.00 & 1.21 & NS \\
\hline Corolla color [1 = white, 2 = green-white, $5=$ violet $]$ & $1=77 \%, 5=23 \%$ & $1=99 \%, 2=1 \%$ & 4.26E-09 \\
\hline Corolla spots $[2=$ yellow, $3=$ green/yellow $]$ & $2=100 \%$ & $2=90 \%, 3=10 \%$ & NS \\
\hline Days to maturity $[1=$ early, $9=$ late $]$ & 6.60 & 5.70 & 0.022 \\
\hline Degree of pungency $[1=$ sweet, $9=$ pungent $]$ & 6.21 & 5.70 & NS \\
\hline Determinate habit $[1=$ at least $75 \%$ mature at once, $0=$ absent $]$ & 0 & 0.04 & NS \\
\hline Fasiculate $[1=$ present, $0=$ absent $]$ & 0 & 0.09 & NS \\
\hline Fruit corkiness $[0=$ none, $9=$ very high $]$ & 0.04 & 0.06 & NS \\
\hline Fruit length $[\mathrm{cm}]$ & 3.64 & 6.13 & $<0.001$ \\
\hline Fruit neck constriction $[1=$ present, $0=$ absent $]$ & 0 & 0.05 & NS \\
\hline Fruit persistance $[0=$ separating calyx (has $S p$ gene), $0=$ persistant calyx $]$ & 0 & 0.73 & 0.002 \\
\hline Fruit pods per node & 1.00 & 1.01 & NS \\
\hline Fruit position $[1=$ pendant, $9=$ erect $]$ & 5.93 & 1.96 & NS \\
\hline Fruit set $[1=$ low, $9=$ high $]$ & 6.52 & 6.46 & 0.014 \\
\hline Fruit shape $[1=$ elongate, $2=$ oblate, $4=$ conic, $6=$ bell $]$ & $1=71 \%, 2=14 \%, 4=14 \%$ & $1=85 \%, 2=1 \%, 4=10 \%, 6=4 \%$ & NS \\
\hline Fruit weight $[g]$ & 2.20 & 5.40 & $<0.001$ \\
\hline Fruit width $[\mathrm{cm}]$ & 1.22 & 1.92 & 0.001 \\
\hline Immature fruit color [2 = green, 3 = green/yellow, $4=$ yellow, $5=$ white $]$ & $2=75 \%, 3=25 \%$ & $2=58 \%, 3=33 \%, 4=5 \%, 5=4 \%$ & NS \\
\hline Leaf pubescence $[0=$ glabrous, $9=$ excessive $]$ & 0.30 & 0.04 & NS \\
\hline Leaf texture $[1=$ smooth, $9=$ curled $]$ & 1.09 & 1.08 & NS \\
\hline Locule number & $2.78 \mathrm{E}+00$ & $2.80 \mathrm{E}+00$ & 0.027 \\
\hline Mature fruit color [ $2=$ red, $3=$ orange-red, $4=$ yellow, $5=$ orange $]$ & $2=70 \%, 3=10 \%, 5=20 \%$ & $2=82 \%, 3=6 \%, 4=1 \%, 5=12 \%$ & NS \\
\hline Node anthocyanin $[1=$ present, $0=$ absent $]$ & 1.00 & 0.90 & NS \\
\hline Pedicel position at anthesis $[1=$ pendant, $9=$ erect $]$ & 8.57 & 8.59 & NS \\
\hline Peduncle insertion $[1=$ protruded, $9=$ inserted $]$ & 2.74 & 2.92 & NS \\
\hline Peduncle length $[\mathrm{cm}]$ & 3.25 & 4.24 & $<0.001$ \\
\hline Plant habit $[1=$ sprawling, $9=$ tall or upright $]$ & 5.24 & 5.45 & NS \\
\hline Plant height $[\mathrm{cm}]$ & 70.25 & 66.15 & NS \\
\hline Plant width $[\mathrm{cm}]$ & 88.15 & 82.83 & NS \\
\hline Stem anthocyanin $[1=$ present, $0=$ absent $]$ & 0.92 & 0.77 & NS \\
\hline Stem color $[1=$ present, 2 = purple $]$ & 1.00 & 1 & NS \\
\hline Stem number & 5.95 & 6.01 & 0.022 \\
\hline Stem pubescence $[0=$ glabrous, $9=$ excessive $]$ & 1.05 & 0.78 & NS \\
\hline Stigma exsertion [ $1=$ inserted, $9=$ exserted $]$ & 5.04 & 4.24 & NA \\
\hline Wall thickness [cm] & $1.17 \mathrm{E}-01$ & $1.68 \mathrm{E}-01$ & 0.016 \\
\hline
\end{tabular}

${ }_{\mathrm{z}}$-value showing the differences between the wild and domesticated Capsicum baccatum groups; NS, not significant; NA, not available. 


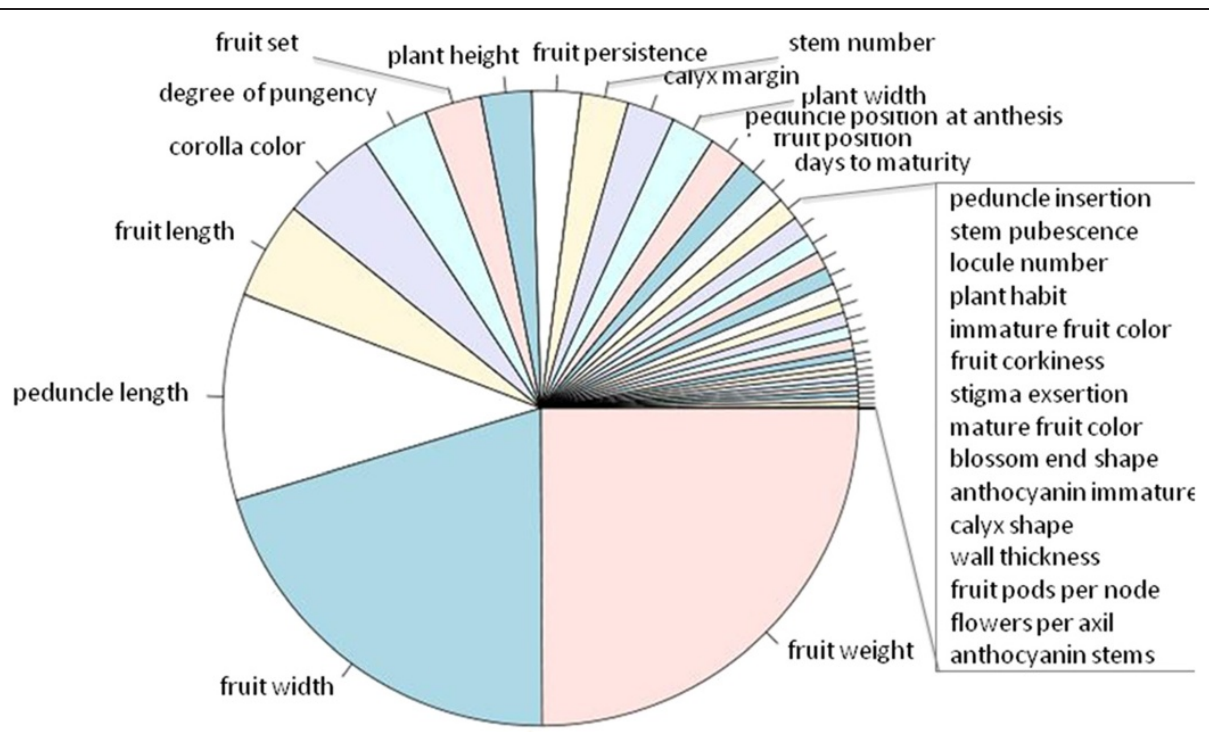

Figure $\mathbf{2}$ Proportional importance of $\mathbf{4 0}$ morphological traits explaining the variation between wild and domesticated accessions. The proportional importance was partitioned by Random Forest regression analysis (RandomForest, ver. 3.1).

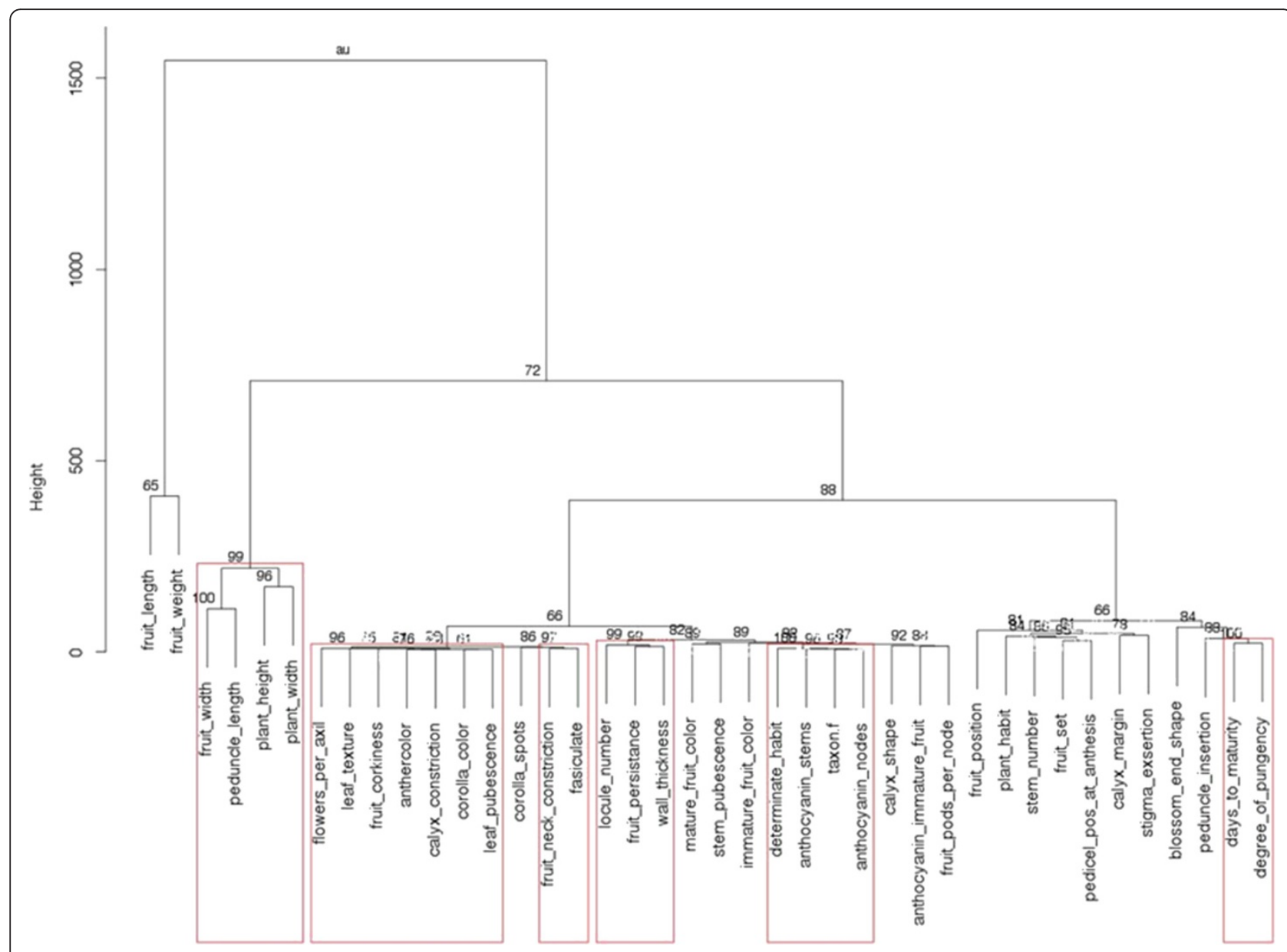

Figure 3 Dendrogram depicting the relationship among 39 morphological traits in 177 accessions of Capsicum baccatum. Distance measure of Minkowski [15] with 1,000 bootstrapping was used. AU values (\%) are shown. 


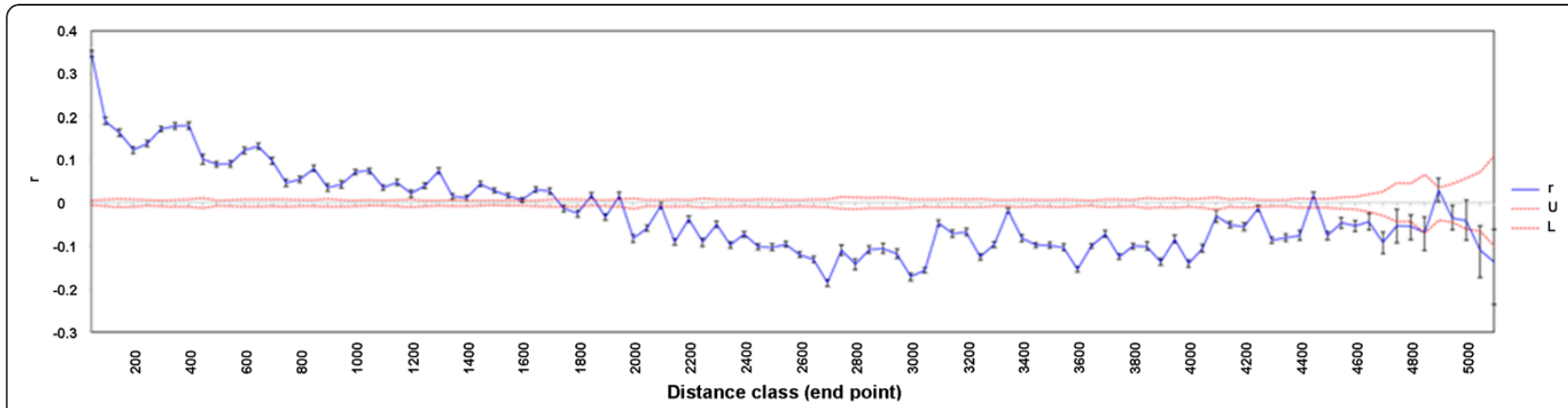

Figure 4 Spatial autocorrelograms for 190 accessions of Capsicum baccatum var. pendulum showing the global spatial correlation (rc) as a function of geographical distance. The $95 \%$ confidence interval about the null hypothesis of a random distribution was determined by bootstrapping. Even distance windows of $50 \mathrm{~km}$ were used with a limits of dispersal for C. baccatum var. pendulum at a distance of ca. 1,750 km.

cultivated and wild Capsicum genetic resources [18]. Wild and ancestral species of tomato, a related member of the Solanaceae, share an equally broad geographic distribution in South America from near sea level to over $3,300 \mathrm{~m}$ elevation, with habitat ranging from arid coastal lowlands to mesic uplands [19,20]. Analogous to Capsicum genetic diversity, the Andean geography, varied ecological habitats and different climates have contributed to wild tomato diversity [21]. Temperature extremes, as well as the amount and distribution of precipitation are often limiting factors to distribution of wild forms of a species and to a lesser extent cultivated forms. Ecological clines, i.e. associations between climatic conditions and a plant's morphological or genetic patterns, arise as a consequence of migration and adaptations.
The ecological distribution of the C. baccatum accessions evaluated in this study indicated that domesticated accessions occupied habitat with rainfall as low as $3 \mathrm{~mm}$ per year, probably because of the option for irrigation. Wild forms of the species were restricted to areas of higher rainfall since cultivation is lacking. Likewise, cool temperatures in summer may represent a barrier to the distribution of wild forms of C. baccatum, as only domesticated types are found in areas where the maximum temperatures remain below $25^{\circ} \mathrm{C}$. Genetic variation for pepper tolerance to moderately cold temperatures has been reported [22]. Assessment of five species including C. annuum, C. frutescens, C. chinense, C. baccatum and $C$. pubescens, revealed significant differences in low temperature $\left(13^{\circ} \mathrm{C}-18^{\circ} \mathrm{C}\right)$ seed emergence

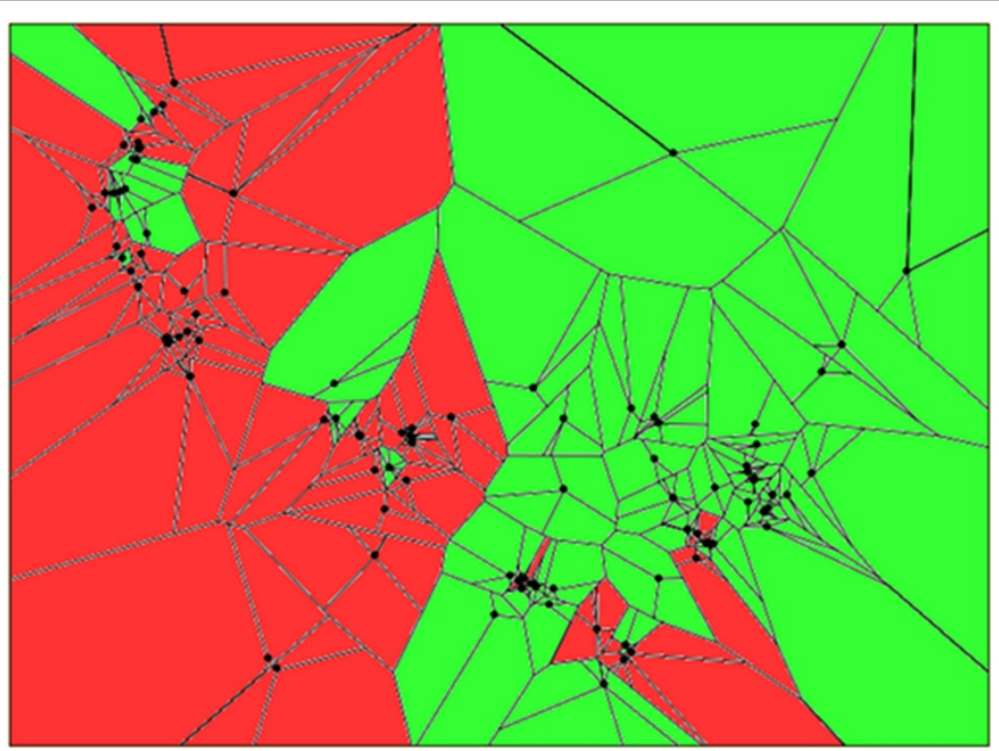

Figure 5 Inferred clusters in the domesticated Capsicum baccatum accessions using a spatial population genetic analysis. Analysis was based on the Bayesian clustering algorithm (Tess ver. 2.3.1; [16]). Points represent accessions and lines denote neighborhood networks based on Voronoi tessellation. Colors illustrate cluster membership. The parameter of burn in was set as 10,000 and the total number of sweeps was 50,000. Admixture was assumed and accounted for by the CAR model [17]. Runs were computed at $K=2$ to $K=4 . K=3$ is shown. 
between accessions within species and a significantly greater seedling emergence score at low temperature for an accession of $C$. baccatum var. pendulum relative to all species accessions evaluated [22]. Similar to pepper, cold tolerance has been identified in wild as well as domesticated accessions of related Solanaceous crops that are native to temperate parts of the world where they may experience low temperatures [23,24]. For example, Solanum lycopersicum and S. habrochaites accessions native to Turkey and Peru, respectively, exhibited cold tolerance during seed germination as well as during vegetative growth [25].

Locally adapted populations of wild plant species typically differ in their responses to abiotic stresses, including extremes of moisture and temperature. Differences with respect to climatic factors between wild and domesticated forms of $C$. baccatum were not significant, possibly due to the low representation of wild accessions. Both wild and domesticated forms occur in areas with chilling or freezing temperatures; however, tolerance to low temperatures is likely more important for wild types which are perennial than for domestic forms that are grown seasonally. In climates with warmer temperatures, farmers had the opportunity to select for varieties with earlier flowering or shorterened fruit development time spanning the period from anthesis to fruit maturity. Despite the option for use of supplemental irrigation of cultivated forms, large fruit set in C. baccatum is only obtained in accessions collected from geographic areas with natural occurrence of high rainfall.

Apart from having its geographic center further west and north, the average annual temperature recorded for accessions in the western group is more than $1^{\circ} \mathrm{C}$ lower in comparison to accessions that comprise the eastern group. In addition, the annual rainfall as well as the precipitation amount during the warmest quarter is far less in the west in comparison to the east.

\section{Variation of morphological traits in the wild and domesticated $C$. baccatum}

The present study revealed a high level of morphologic diversity, compatible with a prior report cataloguing aspects of C. baccatum morphological diversity [26]. Our results demonstrate morphological differences between the eastern and western groups that delineate the distribution range of wild and domesticated botanical forms of C. baccatum. Fruit attributes that contribute to yield potential, e.g. fruit weight, width and wall thickness, were generally greater in domesticated accessions occupying the eastern range in comparison to accessions from the western group. The differences in these domestication traits are likely the result of human selection and may reflect differences in cultural preferences between east and west.

Fruit traits in the domesticated $C$. baccatum accessions have been subjected to human selection $[2,27,28]$. Multiple factor analysis, MANOVA and random forest correlation identified fruit morphology as the most important phenotypic variable in $C$. baccatum. Out of the 40 morphological traits evaluated, we identified yield attributes that include fruit weight, fruit length and peduncle length as most informative for discrimination between wild ( $C$. baccatum var. baccatum) and domesticated (C. baccatum var. pendulum) accessions. Fruit weight is clearly greater in domesticated accessions, as a result of enhanced fruit length, width and thicker fruit walls. Fruit width has greater importance than fruit length in the discrimination between wild and domesticated types; however, cluster analysis suggested that fruit length has a greater impact on final fruit weight. Studies in related Solanaceous crops suggest that a relatively small number of genes may account for the variation that discriminate wild and domesticated fruit of C. baccatum. In tomato, six loci explain much of the difference in fruit size evident between small fruited wild tomato species and their domesticated large fruited counterparts [29]. Orthologs of a number of these genes also account for size differences between small fruited ancestral eggplant species and large fruited commercial eggplant cultivars [30].

Differences in fruit morphology have been utilized to differentiate C. baccatum var. baccatum from $C$ baccatum var. pendulum [7,31]. Subsequent analyses suggested that morphological differences between wild and domesticated types were not clear cut $[2,3]$. While we demonstrated that fruit yield-related attributes are robust indicators of varietal status, significant differences between varietal forms were also evident for traits including fruit anthocyanin pigmentation and fruit persistence. Related fruit attributes such as mature red pod color and upright peduncle orientation which are generally considered unique to wild varieties for bolstering bird predation and seed dissemination, did not distinguish wild from domesticated forms. For example, we found a number of domesticated varieties with small, erect fruit, and conversely, also wild types with larger, pendant fruit. A plausible explanation for this result may be the fact that $C$. baccatum is used as spice, and the use as a spice does not necessarily require substantial remodeling of fruit morphological traits such as increasing the fruit size, which would have led to a downward orientation of the peduncle. Our analyses and the descriptive results reported by [26] demonstrate introgresion of morphological characters among the botanical varieties. Wild and domesticated forms of the species are interfertile. Thus, hybridization likely accounts for 
much of this assimilation, particularly for geneflow from domesticated to wild accessions. Cultivation discourages geneflow from wild to domesticated genepools [12].

While most wild accessions bear fruit that produce anthocyanin when immature, that trait has largely been lost through human intervention during development of domesticated forms. Similar to anthocyanin in fruit, violet corollas are absent in the domesticated pool. Whereas fruit anthocyanin has been lost in domesticated accessions due to human selection, violet corollas are lacking in the lineage that contributed to domesticated forms of the species. Violet corollas are a trait that is exclusive to C. baccatum var. praetermissum wild types from Brazil. Our prior genetic analysis demonstrated that this wild form of $C$. baccatum is distinct and has not contributed to the domesticated pool [12]. Cluster analyses suggested an early divergence of the C. baccatum var. praetermissum lineage prior to C. baccatum domestication.

Cluster analysis of morphological traits demonstrated that anthocyanin pigmentation in vegetative plant parts (nodes, stems) is correlated but independent of anthocyanin accumulation in fruit. These observations are consistent with inheritance studies demonstrating simple inheritance for fruit anthocyanin pigmentation in Capsicum reproductive tissues and a complex inheritance for pigmentation in vegetative tissue [32].

Overall, the degree of fruit pungency was positively associated with days to maturity. The latter was inversely related to both maximum temperature and annual temperature. Although relationships between the degree of pungency and climatic factors were not significant, accessions with the highest pungency scores more often originated from warmer climates. Environmental factors, natural or brought upon by human intervention, such as temperature, light and fertilization level at the time of fruit maturation can influence fruit capsaicinoid concentration and pungency level and contribute to significant genotype $\mathrm{x}$ environement effects for this attribute [33-35]. Capsaicinoids are secondary metabolites that serve to deter predation by mammals with little effect on seed dispersal by birds since they do not sense capsaicinoid pungency.

Plant height is reduced and stem number increased among domesticated accessions in the 'western' group as based on both cluster [12] and Bayesian spatial analysis. Our data suggest that this is not a function of higher altitudes and cooler temperatures in the western territories. In fact, at lower temperatures, more erect plant habits are observed with thereby increased plant height, which may be a consequence of direct or indirect local human selection. A study of global patterns in plant height found that a wide range of height strategies were present in cold, dry, low productivity systems, but a lack of very short species in wetter, warmer, more productive sites [36]. That study found that the best model for global patterns in plant height included just one variable, precipitation in the wettest month. The longer maturation time and the lower fruit set observed for western C. baccatum accessions may be a consesquence of adaptations to climatic differences among the regions occupied by the western and eastern groups, i.e. based on lower temperatures and annual rainfall in western territories. Fruit set increased with annual rainfall, and highest fruit set was only observed in regions with at least $1,000 \mathrm{~mm}$ annual rainfall. In warmer habitats, maturation time or days to maturity were reduced. Alternatively or in addition to a scenario shaped by natural selection forces, human selection pressures for higher fruit set and shorter maturation times in the east may also have been stronger in this region in comparison to the west. Both annual rainfall and annual temperature are reduced in the western territories. In a study of two wild Andean tomato species, [37] proposed that local, regional, and species-wide environmental conditions are responsible for phenotypic and physiological diversification. Supportive of our results, Nakazato et al. [37] identified temperature and precipitation gradients as the strongest trait-environment associations, suggesting that those climatic factors are predominant drivers of adaptive diversification, at least in wild types. Due to assimilation of morphological attributes between wild and domesticated forms of C. baccatum, the relative role of natural selection versus human selection as drivers of morphological traits in the domesticated pool cannot be estimated from the present data.

\section{Spatial structure in domesticated $C$. baccatum}

The domesticated C. baccatum germplasm was highly admixed and distributed across distant and ecologically diverse geographic regions. This is an indication that the domesticated $C$. baccatum remained well connected through gene flow. Over long distances, natural dispersal agents such as insects (pollen) and birds (seeds) likely play a less significant role for gene flow of domesticated material relative to human activities such as trade, because of much higher mobility based on the technical means of human transport [38]. A clear 'immigrant' identity was detected from the far end of the gene pool, i.e. among accessions that are separated by $3,000 \mathrm{~km}$, demonstrating that human mediated, long-distance seed exchange occurred among distant regions. This result is in congruence with other domesticated crops such as beans [39] and maize [40] which exhibited significant seed-flow across long distances, in amounts and across distances where only transport by humans is possible. However, our results are contrary with a study of Mexican C. annuum populations [41], which suggested that 
human activities do not necessarily result in increased long distance gene flow relative to natural dispersal. The fact that 'immigrants' or introductions did not hybridize with local types indicates that: a) long-distance seed displacement occurred fairly recently; therefore, their genetic identity has not yet been obscured, or b) the specificities of the introduced types were maintained deliberately for their ethno-botanical purpose. Evidence for preservation of specific lineages within this C. baccatum germplasm was previously identified using AFLP markers for a group of accessions that form a distinct subclade nested within the predominantly Brazilian 'eastern' clade [12]. We called this group of Brazilian accessions the 'umbilicatum' clade as one of its member accessions was described as C. baccatum var. umbilicatum. This botanical variety was recently established [42]. This group exhibited greater divergence from the remainder of the accessions in the 'eastern' group, and was comprised of accessions from two areas of Brazil separated by over $1000 \mathrm{~km}$. Conversely, other accessions in geographic proximity to 'umbilicatum' types were only distantly related to that subgroup. The role of ecological factors and agricultural selection in maintenance of landraces of pepper [43] and eggplant [44], Solanaceous relatives, have been reported.

Significant correlations were found between genetic and geographic distance with respect to the western and eastern subgroups of domesticated C. baccatum. Moreover, regional spatial structure was detected (within $100 \mathrm{~km}$ ) in domesticated C. baccatum. The structure weakened after $100 \mathrm{~km}$, although remained detectable up to almost 2,000 km. Adaptations to local ecological conditions may be responsible for regional differentiation. Our results are in congruence with a scenario of overlapping, short- to medium-distance trading units within the domesticated pool, which leave a signature of gradual decline in relatedness with increasing distance.

The observed spatial structure supports the conclusion that the distribution of C. baccatum var. pendulum genotypes is not random at the sampled geographical scale. Proximate genotypes tend to be more genetically similar than distant ones, consistent with the isolation by distance pattern of many other tropical species [37,45-47].

Multiple domestication events were proposed for the species' based on the pattern of AFLP genetic admixture between wild and domesticated forms [12]. Our current results for spatial population analysis revealed separation of the western and eastern groups coincident with the political borders for Peru/Bolivia and Paraguay/Brazil. Wild accessions from areas that today comprise Bolivia and Peru were proposed as progenitors to the domesticated germplasm from these regions (the 'western' group), whereas Paraguayan wild types showed associations with the domesticated accessions from the same area [12]. The present results based on Bayesian spatial clustering methodology also demonstrate that each of the two sub-gene pools (the western and eastern) is homogeneous; indicating that the significant spatial genetic structure in each sub-gene pool is not due to recent colonization. The observed isolation by distance event in these two sub-gene pools therefore further support the hypothesis that the cultivated $C$. baccatum was domesticated independently in two sites, one in the Andes highlands (Peru/Bolivia) band and the other in the lowland of Paraguay.

\section{Conclusions}

In summary, the present study mapped the ecogeographic distribution, analyzed the spatial genetic structure, and assessed the relationship between the spatial genetic pattern and the variation of morphological traits in a diverse $C$. baccatum germplasm collection spanning the species distribution range. We demonstrated that this species covers a great scope of ecogeographic diversity in South America, ranging from cool Andean highland to Amazonia rainforest. The high level of morphological diversity, with fruit weight as the leading variable, was revealed in a distribution pattern compatible to the AFLP-based two regional groups (western and eastern). The division of the domesticated germplasm into two major groups based on AFLP analysis was further supported by significant spatial structure. The results obtained further improve our understanding of the organization of the C. baccatum gene pool, thus enhancing the efficiency of conservation and utilization of this important Capsicum species.

\section{Methods}

\section{Plant material}

Seeds and passport data of C. baccatum accessions of all four known botanical varieties which includes the wild C. baccatum var. baccatum and C. baccatum var. praetermissum, and the domesticated C. baccatum var. pendulum and $C$. baccatum var. umbilicatum, from across the species' entire distribution range, were obtained from the USDA, ARS Capsicum germplasm collection (USDA, ARS, Plant Genetic Resources Conservation Unit, Griffin, GA; Germplasm Resources Information Network [GRIN]; http://www.ars-grin.gov/) [48]. Selected accessions were representative of all countries that lie within the distribution range of the species and were chosen to maximize geographic distribution across the range. Wild $C$. baccatum germplasm is of limited availability in the ex situ collection, particularly for C. baccatum var. baccatum from Brazil (Jarret, personal communication). Passport data and accession IDs are reported in Albrecht et al. [12]. A total of 220 accessions were evaluated. Geographic information 
was available for 190 accessions and morphological data was available for 170 accessions. This included 20 accessions of C. baccatum var. baccatum, 197 C. baccatum var. pendulum accessions, two $C$. baccatum var. praetermissum and one C. baccatum var. umbilicatum accession (Table 1).

Five plants of each accession were grown in the field at the Beltsville Agricultural Research Center at Beltsville, Maryland using a completely randomized design [12]. Leaf tissue sampling, DNA extractions, AFLP fingerprinting and genetic diversity analysis (pairwise genetic distances derived from Jaccard genetic similarities) are described in [12]. Data comprising 40 morphological and physiological descriptors (see Table 4) for the C. baccatum germplasm collection was kindly provided by the USDA, ARS Plant Genetic Resources Conservation Unit and is available from GRIN. Climate data was obtained from DIVA GIS (http://www.worldclim.org) [14].

\section{Ecogeographic distribution}

Wild C. baccatum var. baccatum, C. baccatum var. praetermissum and the domesticated $C$. baccatum var. pendulum and C. baccatum var. umbilicatum accessions that comprise the germplasm collection were collected from a wide range of ecogeographic areas in South America with varied environments. To summarize the ecogeographic distribution of this collection, the average, range and variance of the 'cornerstone' climatic/ geographic factors, i.e. those known to have the largest impact on plant physiology, including longitude, latitude, altitude, average annual temperature and rainfall, temperature extremes in the coldest/warmest month of the year and rainfall occurrence during the warmest season were computed using DIVA-GIS ver. 5.2.02 [14]. DIVAGIS was also utilized for constructing the distribution map of the C. baccatum collection.

\section{Ecogeographical condition and morphological trait relationships}

Logistic regressions were performed using the Proc REG procedure of SAS (SAS Institute Inc. 2008. SAS/STAT ${ }^{\circledR}$ 9.2User's Guide. Cary, NC: SAS Institute Inc.) to test for relationships between plant morphological traits and geographical locations and ecological conditions. Basic statistical descriptors and the test for differences between subgroups of $C$. baccatum derived from wild $C$. baccatum var. baccatum and $C$. baccatum var. praetermissum and the domesticated C. baccatum var. pendulum and C. baccatum var. umbilicatum were computed using $\mathrm{R}$ with the package 'BSDA' (ver. 2.11.1). Breiman's Random Forest algorithm (RandomForest, ver. 3.1) was implemented for regressions among morphological and taxonomic features. Multivariate analysis of variance (MANOVA) was computed using $\mathrm{R}$ with the package 'stats'. Dendrograms were computed with 10,000 bootstraps using R 'pvclust' with clustering measure 'Ward' and distance measure 'Minkowski' [15].

\section{Spatial genetic structure}

Spatial genetic structure (SGS) in the C. baccatum germplasm collection was analyzed using a pairwise comparison of genetic similarity of individuals with respect to spatial distance separating those individuals, as implemented in GenAlEx 6 [49]. The significance of the autocorrelation coefficient ( $\mathrm{r}$ ) was tested by constructing a classic 2-tailed 95\% confidence interval around the null hypothesis of no SGS (i.e., $r=0$ ) and by performing 999 random permutations of genotypes among geographic locations [49]. In addition, a Mantel test was performed between the matrix of genetic distances and the linear pairwise geographical distances using the Mantel procedure in the same program. The test was first applied to the domesticated C. baccatum var. pendulum and $C$. baccatum var. umbilicatum accessions, followed by a separate test for the 'western' and the 'eastern' group, as defined by the Bayesian clustering analysis [12]. The Mantel test was also applied in smaller regions where accession representation was adequate, such as regions in Southern Peru and eastern Brazil. Spatial correlation was not tested for wild $C$. baccatum accessions due to small sample size.

A spatial population genetic analysis based on the Bayesian clustering algorithm (Tess ver. 2.3.1; [16]) was used to assign the domesticated $C$. baccatum accessions to geographical clusters. The parameter of burn in was set as 10,000 and the total number of sweeps was 50,000. Admixture was assumed and accounted for by the conditional autoregressive model (CAR) model [17]. Runs were computed for $k=2$ to $k=4$. For these analyses, only accessions with robust geographic location information were utilized.

\section{Abbreviations \\ AFLP: Amplified fragment length polymorphism; GIS: Geographic information system; CAR: Conditional autoregressive model; MANOVA: Multivariate analysis of variance; SGS: Spatial genetic structure; USDA, ARS: United States Department of Agriculture, Agricultural Research Service.}

\section{Competing interests}

Two of the authors (EA and ADM) are employed by Keygene which owns the AFLP trademark.

\section{Authors' contributions}

EA and JRS conceived and designed the study. EA, DZ, RAS and JRS evaluated morphological and geographic data. EA performed genotyping EA, DZ and ADM conducted statistical analyses. EA, DZ and JRS wrote the manuscript. All authors reviewed the results from the data analysis and approved the final manuscript.

\section{Acknowledgements}

The authors thank Judith Dumm, Josh Marvel and Eunhee Park for dedicated technical support. This work was partially supported by a Cooperative Research and Development Agreement (58-3 K95-8-1253) with Keygene Inc. 
AFLP is a registered trademark of Keygene n.v. Mention of trade names or commercial products is solely for the purpose of providing specific information and does not imply recommendation or endorsement by the United States Department of Agriculture.

\section{Author details}

'Keygene Inc., 155 Gibbs Street, Suite 405, Rockville, MD 20850, USA. ${ }^{2}$ United States Department of Agriculture, Agriculture Research Service, Beltsville Agricultural Research Center, Plant Sciences Institute, Sustainable Perennia Crops Laboratory, Beltsville, MD 20705, USA. ${ }^{3}$ United States Department of Agriculture, Agriculture Research Service, Beltsville Agricultural Research Center, Plant Sciences Institute, Food Quality Laboratory, Beltsville, MD 20705, USA. ${ }^{4}$ United States Department of Agriculture, Agriculture Research Service, Beltsville Agricultural Research Center, Plant Sciences Institute, Genetic Improvement of Fruits and Vegetables Laboratory, Beltsville, MD 20705, USA.

Received: 28 February 2012 Accepted: 27 July 2012

Published: 6 August 2012

\section{References}

1. Dijan-Caporalino C, Lefebvre V, Sage-Daubèze AM, Palloix A: Capsicum. In Genetic Resources, Chromosome Engineering, and Crop Improvement. Vol 3 , Vegetable Crops. Edited by Singh RJ, Jauhar PP. Boca Raton: CRC Press/Taylor and Francis Group; 2006:186-245.

2. Eshbaugh WH: The taxonomy of the genus Capsicum (Solanaceae). Phytologia 1980, 47:153-166.

3. Pickersgill B, Heiser CB, McNeill J: Numerical taxonomic studies on variation and domestication in some species of Capsicum. In The Biology and Taxonomy of the Solanaceae, Linnaean Society Symposium, Volume Series Number 7. Edited by Hawkes JG, Lester RN, Skelding AC. London: Academic Press; 1979:679-700.

4. D'Arcy WG, Eshbaugh WH: New World peppers (Capsicum-Solanaceae) north of Colombia: A resume. Baileya 1974, 19:93-105.

5. Pickersgill B: The archaeological record of chili peppers (Capsicum spp.) and the sequence of plant domestication in Peru. Amer Antiquity 1969, 34:54-61.

6. Bosland PW, Votava EJ: Peppers: Vegetable and Spice Capsicums. 2nd edition. Cambridge, MA, USA: CABI; 2012.

7. Eshbaugh WH: A biosystematic and evolutionary study of Capsicum baccatum (Solanaceae). Brittonia 1970, 22(1):31-43

8. Hunziker AT: Estudios sobre Solanaceae. I. Sinopsis de las species silvestris de Capsicum de Argentina y Paraguay. Darwiniana (Buenos Aires) 1950, 9:225-247.

9. Eshbaugh WH: XII. Genetic and biochemical systematic studies of chili peppers (Capsicum-Solanaceae). Bul Torrey Bot Club 1976, 102:396-403.

10. McLeod MJ, Guttman SI, Eshbaugh WH, Rayle RE: An electrophoretic study of evolution in Capsicum (Solanaceae). Evolution 1983, 37(3):562-574

11. Perry L, Dickau R, Zarillo S, Holst I, Pearsall DM, Piperno DR, Berman MJ, Cooke RG, Rademaker K, Ranere AJ, Raymond JS, Sandweiss DH, Scaramelli F, Tarble K, Zeidler JA: Starch fossils and the domestication and dispersal of chili peppers (Capsicum spp. L.) in the Americas. Science 2007, 315:986-988.

12. Albrecht E, Zhang D, Saftner RA, Stommel JR: Genetic diversity and population structure of Capsicum baccatum genetic resources. Genet Resour Crop Evol 2011, 59:517-538.

13. Brown AHD: Core collections. A practical approach to genetic resources management. Genome 1989, 31(2):818-824.

14. Hijmans RJ, Cruz M, Rojas E, Guarino L: DIVA-GIS, version 1.4. A geographic information system for the management and analysis of genetic resources data. Lima, Peru: Manual, Internat Potato Center and Internat Plant Genet Res Inst; 2001. http://www.worldclim.org.

15. Suzuki R, Shimodaira H: Pvclust: an R package for assessing the uncertainty in hierarchical clustering. Bioinformatics 2006, 22:1540-1542.

16. Chen $C$, Durand $E$, Forbes $F$, François $O$ : Bayesian clustering algorithms ascertaining spatial population structure: A new computer program and a comparison study. Mol Ecology Notes 2007, 7:747-756.

17. Durand E, Jay F, Gaggiotti OE, François $O$ : Spatial inference of admixture proportions and secondary contact zones. Mol Biol Evolution 2009, 26(9):1963-1973.
18. Bosland PW, Votava E: Peppers: Vegetable and Spice Capsicums. Oxford, UK: CABI Publishing; 1999.

19. Rick CM: Potential genetic resources in tomato species: Clues from observations in native habitats. In Genes, Enzymes and Populations. Edited by Srb AM. New York: Plenum Press; 1973:255-269.

20. Rick CM, Holle M: Andean Lycopersicon esculentum var. cerasiforme: Genetic variation and its evolutionary significance. Economic Bot 1990 43(3 Suppl):69-78.

21. Warnock SJ: A review of taxonomy and phylogeny of the genus Lycopersicon. HortScience 1988, 23:669-673.

22. Gerson R, Honma S: Emergence response of the pepper at low soil temperature. Euphytica 1978, 27:151-156.

23. Vallejos CE: Genetic diversity of plants for response to low temperature and its potential use in crop plants. In Low-temperature Stress in Crop Plants. Edited by Lyons JM, Graham D, Raison JK. New York: Academic Press; 1979:473-489

24. Wolf S, Yakir D, Stevens MA, Rudich J: Cold temperature tolerance of wild tomato species. J Am Soc Hort Sci 1986, 111:960-964.

25. Foolad MR, Lin GY: Relationship between cold tolerance during seed germination and vegetative growth in tomato: germplasm evaluation. J Amer Soc Hort Sci 2000, 125:679-683.

26. Jarret R: Morphologic variation for fruit characteristics in the USDA/ARS Capsicum baccatum L. germplasm collection. Hort Science 2007 42:1303-1305

27. McLeod MJ, Guttman SI, Eshbaugh WH: Early evolution of chili peppers (Capsicum). Econ Bot 1982, 36:361-368.

28. Pickersgill B: Relationships between weedy and cultivated forms in some species of chili peppers (Genus Capsicum). Evolution 1971 25(4):683-691.

29. Tanksley SD: The genetic, developmental, and molecular bases of fruit size and shape variation in tomato. Plant Cell 2004, 16:S181-S189.

30. Doganlar S, Frary A, Daunay MC, Lester RN, Tanksley SD: Conservation of gene function in the Solanaceae as revealed by comparative mapping of domestication traits in eggplant. Genetics 2002, 161:1713-1726.

31. Jensen RJ, McLeod MJ, Eshbaugh WH, Guttman SI: Numerical taxonomic analyses of allozymic variation in Capsicum (Solanaceae). Taxon 1979, 28:315-327

32. Stommel JR, Griesbach RJ: Inheritance of fruit, foliar and plant habit attributes in Capsicum L. J Am Soc Hort Sci 2008, 133:396-407.

33. Harvell K, Bosland PW: The environment produces a significant effect on pungency of chiles. HortScience 1997, 32:1292.

34. Suzuki T, Iwai K: Constituents of red pepper species: Chemistry, biochemistry, pharmacology and food science on the pungent principle of Capsicum species. In The Alkaloids. Edited by Brossi A. Orlando: Academic Press; 1984:227-299.

35. Zewdie Y, Bosland PW: Evaluation of genotype, environment, and genotype-by-environment interaction for capsaicinoids in Capsicum annuum L. Euphytica 2000, 111:185-190.

36. Moles AT, Warton DI, Warman L, Swenson NG, Laffan SW, Zanne AE, Pitman A, Hemmings FA, Leishman MR: Global patterns in plant height. J Ecology 2009, 97(5):923-932.

37. Nakazato T, Bogonovich M, Moyle LC: Environmental factors predict adaptive phenotypic differentiation within and between two wild Andean tomatoes. Evolution 2008, 62:774-792.

38. Wichmann MC, Alexander MJ, Soons MB, Galsworthy S, Dunne L, Gould R, Fairfax C, Niggemann M, Hails RS, Bullock JM: Human mediated dispersal of seeds over long-distances. Proc Royal Soc Series B 2009, 276:523-532.

39. Papa R, Gepts P: Asymmetry of gene flow and differential geographical structure of molecular diversity in wild and domesticated common bean (Phaseolus vulgaris L.) from Mesoamerica. Theor Appl Genet 2003 106:239-250.

40. Pressoir G, Berthaud J: Patterns of population structure in maize landraces from the Central Valleys of Oaxaca in Mexico. Heredity 2004, 92:88-94.

41. Aguilar-Meléndez A, Morrell PL, Roose ML, Kim SC: Genetic diversity and structure in semiwild and domesticated chiles (Capsicum annuum; Solanaceae) from Mexico. Am J Bot 2009, 96(6):1190-1202.

42. Hunziker AT, Barboza GE: Estudios sobre Solanaceae XLV. Sobre la presencia de Exodeconus en Argentina y una novedad en Capsicum baccatum. Kurtziana 1998, 26:23-31. 
43. Portis E, Nervo G, Cavallanti F, Barchi L, Lanteri S: Multivariate analysis of genetic relationships between Italian pepper landraces. Crop Sci 2006, 46(6):2517-2525

44. Muñoz-Falcón JE, Prohens J, Vilanova S, Nuez F: Characterization, diversity, and relationships of the Spanish striped (Listada) eggplants: a model for the enhancement and protection of local heirlooms. Euphytica 2008, 164(2):405-419.

45. Albrecht E, Escobar M, Chetelat RT: Genetic diversity and population structure in the tomato-like nightshades Solanum lycopersicoides and S. sitiens. Ann Botany 2010, 105:535-554

46. Caicedo AL, Schaal BA: Population structure and phylogeography of Solanum pimpinellifolium inferred from a nuclear gene. Mol Ecology 2004 , 13:1871-1882.

47. Hamrick JL, Murawski D, Nason JD: The influence of seed dispersal mechanisms on the genetic structure of tropical tree populations. Vegetatio 1993, 107-108:281-297.

48. Germplasm Resources Information Network. http://www.ars-grin.gov/.

49. Peakall R, Smouse PE: GENALEX 6: genetic analysis in Excel. Population genetic software for teaching and research. Mol Ecology Notes 2006, 6:288-295.

doi:10.1186/1471-2156-13-68

Cite this article as: Albrecht et al:: Genetic diversity in Capsicum

baccatum is significantly influenced by its ecogeographical distribution.

BMC Genetics 2012 13:68.

\section{Submit your next manuscript to BioMed Central and take full advantage of:}

- Convenient online submission

- Thorough peer review

- No space constraints or color figure charges

- Immediate publication on acceptance

- Inclusion in PubMed, CAS, Scopus and Google Scholar

- Research which is freely available for redistribution 